\title{
Analisis Faktor- Faktor Yang Mempengaruhi Keputusan Nasabah Dalam Memilih Produk Gadai Emas Menurut Perspektif Ekonomi Islam
}

\author{
Sofyan Bachmid, ${ }^{1}$ Indah Musyawarah ${ }^{2 *}$, Noor Riefma Hidayah ${ }^{3}$ \\ Dede Arseyani Pratamasyari ${ }^{4}$ \\ ${ }^{1}$ Jurusan Ekonomi Syariah, Fakultas Ekonomi dan Bisnis Islam, IAIN Palu \\ ${ }^{2}$ Jurusan Perbankan Syariah, Fakultas Ekonomi dan Bisnis Islam, IAIN Palu, \\ ${ }^{3}$ Jurusan Ekonomi Syariah, Fakultas Ekonomi dan Bisnis Islam, IAIN Palu \\ ${ }^{4}$ Jurusan Ekonomi Syariah, Fakultas Ekonomi dan Bisnis Islam, IAIN Palu
}

\begin{abstract}
ABSTRAK
INFORMASI

ARTIKEL

Penelitian ini bertujuan untuk mengetahui pengaruh nilai taksir, biaya ijarah dan pelayanan terhadap keputusan nasabah memilih produk gadai emas di Bank Syariah Mandiri Cabang Palu secara simultan dan parsial. Metode yang digunakan dalam penelitian ini adalah metode kuantitatif. Penentuan sampel menggunakan teknik non probability sampling dengan metode accidental sampling dan berdasarkan rumus slovin ditentukan jumlah sampel sebanyak 82 orang. Teknik pengumpulan data menggunakan observasi, kuisioner, wawancara dan dokumentasi. Teknik uji dan analisis data meliputi uji validitas, uji reliabilitas, uji asumsi klasik, uji regresi linier berganda dengan uji $\mathrm{F}$ dan uji $\mathrm{T}$ serta koefisien determinasi dengan menggunakan SPSS 16 for windows. Hasil yang diproleh dari penelitian ini menunjukkan bahwa faktor nilai taksir, biaya ijarah dan pelayanan berpengaruh secara signifikan terhadap keputusan nasabah memilih produk gadai emas dengan nilai $\mathrm{F}$ hitung sebesar $10.146>$ F tabel 2,72 dengan nilai sig sebesar 0,000. Nilai taksir tidak memiliki pengaruh yang signifikan dikarenakan $\mathrm{F}$ hitung $1,764<\mathrm{F}$ tabel 1,994 dengan sig $0.082>0.05$ dengan besar pengaruh sebesar $17,7 \%$, biaya ijrah memberikan pengaruh yang signifikan dengan nilai $\mathrm{F}$ hitung 2,705 $>\mathrm{F}$ tabel 1,994 dengan sig $0.008<0.05$ dengan besar pengaruh sebesar $27,1 \%$, dan pelayanan sangat berpengaruh sangat signifikan dengan nilai $\mathrm{F}$ hitung 4,558 > F tabel 1,994 dengan sig $0.000<0.05$ dengan besar pengaruh $44,2 \%$, dengan koefisien determinasi sebesar $28,1 \%$ dan $71,9 \%$ dipengaruhi oleh variabel lain tidak diteliti dalam penelitianini. Melalui penelitian ini diharapkan bank tetap mempertahankan dan meningkatkan pelayanan dan biaya ijarah serta diharapkan agar bank lebih memperhatikan nilai taksir agar nasabah lebih mengetahui nilai taksir emas beredar pada saat itu.
\end{abstract}




\section{Jurnal Ilmu Perbankan dan Keuangan Syariah Vol. 1 No. 2 Tahun 2020}

\section{PENDAHULUAN}

Pada dasarnya lembaga keuangan merupakan sebuah perantara dimana lembaga tersebut mempunyai peran dan fungsi sebagai lembaga keuangan yang menghimpun dana dari masyarakat yang kelebihan dan menyalurkan dana kepada masyarakat yang kekurangan dana atau membutuhkan dana agar terwujudnya masyarakat yang adil, makmur dan sejahtera. ${ }^{1}$

Seperti yang diketahui lahirnya bank syariah di Indonesia yang merupakan hasil kerja tim MUI adalah dengan dibentuknya PT. Bank Muamalat Indonesia (BMI). Dengan peraturan pemerintah yang diterbitkan dalam undang - undang no 7 tahun 1992 tentang bank syariah. Disamping BMI, saat ini juga telah lahir bank syariah milik pemerintah seperti Bank Syariah Mandiri (BSM). ${ }^{2,}$,

Perbankan syariah memiliki produk yang berbeda dengan perbankan konvensional, mulai dari prinsip, transaksi yang digunakan, produk pembiayaan, akad-akad yang digunakan dalam pemberian pembiayaan. Salah satu produk pembiayaan yang berbeda dari bank konvensional adalah produk gadai pada bank syariah, dimana bank konvensional tidak mempunyai produk gadai seperti di perbankan Syariah yang terdapat dalam website Bank Syariah Mandiri Cabang Palu.

${ }^{1}$ Kasmir, Manajemen Perbankan -EdisiRevisi, (Jakarta: PT Rajawali Pers, 2012).

2Kasmir, Dasar-Dasar Perbankan, (Jakarta:

PT Rajagrafindo Persada, 2003).

${ }^{3}$ Nurdin, N. (2016). The Roles of Information Technology in Islamic Bank Knowledge Management: A study of Two Syariah Banks in Palu. Hunafa: Jurnal Studia Islamika, 13(2), 181-217.
Salah satu kegiatan syariah yang berkembang pesat di masyarakat adalalah yang gadai emas syariah. Gadai emas syariah adalah sistem pembiayaan yang dilakukan oleh perbankan syariah dengan dasar hukum Fatwa Dewan Syariah Nasional Majelis Ulama Indonesia nomor 25/DSNMUI/III/2002 tentan grahn, baik sistem gadainya maupun emas sebagai barang gadainya. ${ }^{4}$

Bank Syariah Mandiri (BSM $)^{5}$ merupakan lembaga keuangan yang ada di kota Palu dengan alamat Jalan Wolter Monginsidi Kota Palu. Bank Syariah mandiri (BSM) merupakan bank milik pemerintah pertama yang melandaskan operasionalnya pada prinsi psyariah. ${ }^{6}$ BSM menjadi salah satu bank syariah yang tumbuh dengan berkembang dengan cepat dan memiliki 737 kantor layanan diseluruh Indonesia, dengan akses lebih dari 196.000 jaringan ATM yang ada dalam website Bank Syariah Mandiri.7,8

${ }^{4}$ Ahmad Rifqi Damarjati, "Analisi FaktorFaktor yang Mempengaruhi Keputusan Nasabah dalam Menggunakan Produk Pembiayaan Gadai Emas Syariah (Studi Kasuspada BPD DIY Syariah CabangCik Di Tiro)", skripsi (Universitas Islam NegeriSunanKalijaga Yogyakarta 2014), http:/ / digilib.uin-suka.ac.id/15965/skripsi

(diakses 9 desember 2018).

5 Selanjutnya disebut BSM

${ }^{6}$ Ahmad Syafi'i Antonio, "Bank Syariah: Dari Teori Ke Praktik" (Cet.1, Jakarta: GemaInsani Press, 2001) hal 26. 12 juli 2019

${ }^{7}$ Www.banksyariahmandiri.com, diakses

${ }^{8}$ Nurdin, N., \& Yusuf, K. (2020).

Knowledge management lifecycle in Islamic bank: the case of syariah banks in Indonesia. International Journal of Knowledge Management Studies, 11(1), 59-80.

https://doi.org/10.1504/ijkms.2020.105073 


\section{Jurnal Ilmu Perbankan dan Keuangan Syariah Vol. 1 No. 2 Tahun 2020}

Adapun produk yang ada pada BSM salah satunya adalah produk pembiayaan gadai emas. Hal ini dikarenakan terus meningkatnya harga emas dan peningkatan tersebut disebabkan karena emas memiliki nilai intrinsik yang lebih stabil dan tahan inflasi dibandingkan mata uang kertas dan dollar.

Dengan meningkatnya jumlah nasabah pada gadai emas pada setiap tahunnya di Indonesia yang terdapat padal aporan tahun BSM. Hal ini tidak lepas dari sejumlah keuntungan yang ditawarkan setiap perbankan syariah yang membuka gadai emas syariah. Melalui produk gadai emas syariah ini masyarakat yang membutuhkan dana mendesak. Bagi masyarakat yang tertarik cara mendapatkannya juga cukup mudah, aman dan cepat dengan princing yang murah. ${ }^{9}$

Gadai adalah produk Lembaga keuangan Syariah yang telah mendapatkan persetujuan dari Majelis Ulama Indonesia dengan fatwa yang dikeluarkan oleh Dewan Syariah Nasional MUI nomor 26/DSNMUI/III/2002 tentang gadai emas yang membolehkan gadai emas berdasarkan prinsip rahn sesuai dengan fatwa DSN nomor 25/DSN-MUI/III/2002 tentang rahn. Fatwa DSN nomor 26/DSNMUI/III/2002 mengatur tentang ongkos dan biaya penyimpanan barang yang ditanggung oleh pegadaian, namun fatwa ini memberikan batasan bahwa ongkos yang dibebankan kepada pegadaian besarnya didasarkan pada pengeluaraan nyata yang dikeluarkan. ${ }^{10}$ Indonesia.
Penetapan nilai taksir yang relative tinggi dan kompetitif yang diterapkan oleh bank syariah akan mampu mendorong nasabah menggunakan produk pembiayaan gadai emas syariah. ${ }^{11}$

Masing - masing lembaga keuangan syariah menetapkan fasilitas pembiayaan gadai emas tentu memiliki pelayanan yang berbeda satu dengan lmbaga keuangan yang lainnnya. Pelayanan yang diberikan oleh bank Syariah dan pegadaian merupakan daya Tarik dan pilihan tersendiri bagi masyarakat dalam menetukan tempat untuk menggadaikan emasnya. Namun pegadaian merupakan Lembaga keuangan yang lebih dikenal dan lebih dekat dengan masyarakat dalam hal menggadaikan barang terutama menggadaikan emas.

Untuk mengembangkan suatu usaha strategi menjadi faktor yang sangat penting agar suatu usaha tetap berjalan dan mampu bersaing. Semakin banyak pesaing maka semakin banyak pula pilihan bagi konsumen untuk memilih produk yang sesuai dengan apa yang diharapkan. Sehingga membuat konsumen lebih pintar dan bijak dalam memilih setiap produk yang ditawarkan oleh lembaga - lembaga keuangan. Dalam proses menawarkan produk kepada konsumen, faktor harga menjadi faktor yang utama dalam setrategi usaha

${ }^{11}$ Ahmad RifqiDamarjati, “Analisi FaktorFaktor yang Mempengaruhi Keputusan Nasabah dalam Menggunakan Produk Pembiayaan Gadai Emas Syariah (Studi Kasus pada BPD DIY Syariah Cabang Cik Di Tiro)", skripsi (Universitas Islam Negeri Sunan Kalijaga Yogyakarta 2014), http://digilib.uin-suka.ac.id/15965/skripsi (diakses 9 desember 2018). 


\section{Jurnal Ilmu Perbankan dan Keuangan Syariah Vol. 1 No. 2 Tahun 2020}

yang paling menentukan konsumen melakukan keputusan pembelian. Bagi jenis usaha gadai ini faktor harga yang diarahkan kepada biaya - biaya yang dikeluarkan oleh nasabah saat memilih bergadai dipegadaian Syariah. ${ }^{12}$

Kepercayaan nasabah yaitu suatu keyakinan nasabah di salah satu produk tertentu, keyakinan ini muncul dari persepsi yang berulang, adanya pembelajaran dan pengalaman. Sebelum calon nasabah mengajukan pembiayaan rahn, calon nasabah langsung mempercayai semuanya kepada pihak gadai di bank syariah mandiri, karena kondisi calon nasabah yang sedang memerlukan kebutuhan yang harus dipenuhi secara mendesak sehingga gadai di bank syariah menjadi solusi yang tepat. adapun sebagian orang yang kurang mempercayai terhadap gadai syariah tetapi masih melanjutkan pengajuan pembiayaan rahn tersebut untuk memenuhi kebutuhannya dan gadaian syariah dapat dengan mudah memberi pembiayaan dengan syarat hanya membawa jaminan.

\section{TINJAUAN PUSTAKA}

\subsection{Pengertian Gadai Syariah}

Gadai Syariah sering diidentikkan dengan rahn yang secara Bahasa diartikan al-tsubut wa al-dawan (tetap dan kekal). Sebagian ulama luhgat memberi arti al-hab (tertahan).Sedangkan definisi al-rahn menurut istilah yaitu menjadikan

\footnotetext{
${ }^{12}$ MukhlisAbid, "Faktor-Faktor Yang MempengaruhiMasayarakatDalamMemilihProdukRa hn Di Kantor CabangPegadaianSyariahCiputat”, skripsi (UIN SyarifHidayatullah Jakarta, 2014), (diakses 3 januari 2018)
}

suatu benda yang mempunyai nilai harta dalam pandangan syarak untuk kepercayaan suatu utang, sehingga memungkinkan mengambil seluruh atau sebagian utang dari benda tersebut. ${ }^{13}$

Gadai atau ar-Rahn merupakan kegiatan menahan salah satu harta milik si peminjam sebagai jaminan atau agunan atas pinjaman yang diterimanya.

Dari kalangan ulama mazhab Maliki mendefinisikan rahn sebagai "harta yang dijadikan pemiliknya sebagai jaminan hutang yang bersifat mengikat", ulama mazhab Hanafi mendefenisikan dengan "menjadikan suatu barang sebagai jaminan terhadap hak (piutang) yang mungkin dijadikan sebagai pembayar hak tersebut, baik seluruhnya maupun sebagian". Ulama syafii dan hambali dalam mengartikan rahn dalam arti akad yakni menjadikan barang sebagai jaminan hutang, yang dapat dijadikan pembayaran utang apabila orang yang berhutang tidak bisa membayar hutangnya. ${ }^{14}$

\subsection{Perilaku Konsumen}

Perilaku konsumenyang tidak secara langsung dikendalikan oleh perusahaan perlu mencari informasi semaksimal mungkin. Banyak pengertian prilaku konsumen yang dikemukan oleh para ahli, salah satunya yang didefenisikan oleh Engel dan kawan-kawan yang mengatkan bahwa:

"perilaku konsumen didefenisikan sebagai suatu tindakan yang langsung mendapatkan,

${ }^{13}$ Hendi Suhendi, Fiqih Muamalah, (edisi 1-8, Jakarta: Rajawali Pers, 2013), hal 106.

${ }^{14}$ Muhammad Sholahuddin, Lembaga Keuangan dan Ekonomi Islam, (Yogyakarta: penerbit ombak, 2014), hal 198. 


\section{Jurnal Ilmu Perbankan dan Keuangan Syariah Vol. 1 No. 2 Tahun 2020}

mengkonsumsi serta menghabiskann produk dan jasa, termasuk proses keputusan yang mendahului dan penyusuli tindakan tersebut". 15

Selanjutnya dapat dijelaskan bahwa prilaku konsumen tadi terbagi dua bagian, yang pertama adalah prilaku yang tampak, variable-variabel yang termasuk ke dalamnya adalah pembelian, waktu, karena siapa, dengan siapa dan bagaimana konsumen melakukan pembelian. Yang kedua adalah prilaku yang tak tampak, variable-variabelnya antara lain adalah persepsi, ingatan terhadap informasi dan perasaan kepemilikan terhadap konsumen.

Terdapat dua faktor utama yang mempengaruhi prilaku konsumen, yaitu faktor social budaya yang terdiri atas kebudayaan, budaya khusus, kelas social, kelompok social dan referensi serta keluarga. Faktor yang lain adalah faktor psikologis yang terdiri atas motivasi, persepsi, proses belajar, kepercayaan dan sikap. Selanjutnya prilaku konsumen tadi sangat menentukan dalam proses pengambilan keputusan membeli yang tahapnya dimulai dari pengenalan masalah yaitu berupa desakan yang membangkitkan tindakan untuk memenuhi dan memuaskan kebutuhannya.

Selanjutnya tahapan mencari informasi tentang produk atau jasa yang dibutuhkan yang dilanjutkan dengan tahap evaluasi alternativeyang berupa penyeleksian. Tahap berikutnya adalah

\footnotetext{
${ }^{15}$ Husein Umar, Riset Pemasaran dan Prilaku Konsumen, (Jakarta: PT Gramedia Pustaka Utama, 2000), hal 50
}

tahapan keputusan pembelian dan diakhiri dengan prilaku sesudah pembelian dimana membeli lagi atau tidak tergantung dari tingkat kepuasan yang didapatkan dari produk atau jasa tersebut. 16

a. Faktor-faktor kebudayaan

1) Kebudayaan

Kebudayaan merupakan faktor penentu yang paling dasar dari keinginan dan prilaku seseorang. Bila makhluk lainnya bertindak berdasarkan naluri, maka perilaku manusia umumnya dipelajari. Seorang anak yang sedang tumbuh mendapatkan seperangkat nilai, persepsi, preferensi dan prilaku melalui suatu proses penting lainnya.

2) Sub-Budaya

Setiap kebudayaan terdiri dari subbudaya, sub-budaya yang lebih kecil yang memberikan identifikasi dan sosialisasi yang lebih spesifik untu para anggotanya. Sub-budaya dapat dibedakan menjadi empat jenis: kelompok nasionalisme, kelompok keagamaan, kelompok ras, dan area geografis.

3) Kelas sosial

Kelas-kelas sosial adalah kelompokkelompok yang relative homogen dan bertahan lama dalam suatu masyarakat, yang tersusun secara hierarki dan keanggotaannya mempunyai nilai, minat dan prilaku yang serupa. ${ }^{17}$

b. Faktor-faktor sosial

1) Kelompok referensi

\section{${ }^{16}$ Ibid, hal 52}

${ }^{17}$ Nugroho J. Setiadi, Prilaku Konsumen, Konsep Dan Implikasi Untuk Strategi Dan Penelitian Pemasaran, (Jakarta: Kencana, 2003), hal 11. 


\section{Jurnal Ilmu Perbankan dan Keuangan Syariah Vol. 1 No. 2 Tahun 2020}

Kelompok referensi seseorang terdiri dari seluruh kelompok yang mempunyai pengaruh langsung maupun tidak langsung terhadap sikap atau prilaku seseorang. Beberapa diantaranya adalah kelompok-kelompok primer, yang dengan adanya interaksi yang cukup berkesinambungan, seperti keluarga, teman, tetangga, dan teman sejawat. Kelompok-kelompok skunder, yang cenderung lebih resmi dan yang mana interaksi yang terjadi kurang berkesinambungan. Kelompok yang seseorang ingin menjadi anggotanya disebut kelompok aspirasi. Sebuah kelompok diasosiatif (memisahkan diri) dan sebuah kelompok yang nilai perilakunya tidak disukai oleh individu.

2) Keluarga

Kita dapat membedakan antar dua keluarga dalam kehidupan pembeli, yang pertama adalah keluarga orientasi, yang merupakan orang tua seseorang. Dari orang tualah seseorang mendapat pandangan tantang agama, politik, ekonomi dan merasakan ambisi pribadi nilai atau harga diri dan cinta. Keluarga prokreasi, yaitu pasangan hidup anakanak seseorang keluarga merupakan organisasi pembeli dan konsumen yang paling penting dalam suatu masyarakat dan telah diteliti secara intensif.

3) Peran dan status

Seseorang umumnya berpartisipasi dalam kelompok selama hidupnya, keluarga, klub, organisasi. Posisi sesesorang dalam setiap kelompok dapat diidentifikasikan dalam peran dan situs. ${ }^{18}$

c. Faktor Pribadi

\footnotetext{
${ }^{18}$ Ibid, hal 12.
}

1) Umur dan tahapan dalam siklus hidup

Konsumsi sesesorang juga dibentuk oleh tahapan siklus hidup keluarga. Beberapa penelitian terakhir telah mengidentifikasi tahapan-tahapan dalam siklus hidup psikologis.Orangorang dewasa biasanya mengalami perubahan atau transformasi tertentu pada saat mereka menjalani hidupnya.

2) Pekerjaan

Para pemasar berusaha mengidentifikasi kelompok-kelompok pekerja yang memiliki minat diatas ratarata terhadap produk dan jasa tertentu.

3) Keadaan ekonomi

Yang dimaksud dengan keadaan ekonomi seseorang adalah terdiri dari pendapatan yang dapat dibelanjakan (tingkatnya, stabilitasnya, dan polanya), tabungan dan hartanya(termasuk presentase yang mudah dijadikan uang), kemampuan untuk meminjam dan sikap terhadap mengeluarkan lawan menabung.

4) Gaya hidup

Gaya hidup seseorang adalah pola hidup didunia yang diekspresikan oleh kegitan, minat dan pendapatan seseorang, gaya hidup menggambatrkan "seseorang secara keseluruhan" yang berintraksi dengan lingkungan. Gaya hidup juga mencerminkan sesuatu dibalik kelas sosial seseorang.

5) Kepribadian dan konsep diri

Yang dimaksud dengan kepribadian adalah karakteristik psikologis yang berbeda dari setiap orang yang memandang responnya terhadap lingkungan yang relative konsisten. Kepribadian dapat merupakan suatu variable yang sangat berguna dalam menganalisis prilaku 


\section{Jurnal Ilmu Perbankan dan Keuangan Syariah Vol. 1 No. 2 Tahun 2020}

konsumen. Bila jenis-jenis kepribadian dapat diklasifikasikan dan memiliki korelasi yang kuat antara jenis-jenis kepribadian tersebut dengan berbagai pilihan dan produk. ${ }^{19}$

d. Faktor-faktor Psikologis

1) Motivasi

Beberapa kebutuhan bersifat boigenik, kebutuhan ini timbul dari suatu keadaan fisiologis tertentu, seperti rasa lapar, rasa haus dan rasa tidak nyaman. Sedangkan kebutuhankebutuhan lain bersifat psikogenik yaitu, kebutuhan yang timbul dari keadaan fisiologis tertentu, seperti kebutuhan untuk diakui, kebutuhan harga diri, atau kebutuhan diterima.

2) Persepsi

Persepsi didefinisikan sebagai proses dimana seseorang memilih, mengorganisasikan, mengartikan masukan informasi untuk menciptakan suatu gambaran yang berarti dari dunia ini. Orang dapat memiliki persepsi yang berbeda dari objek yang sama kerana adanya tiga proses persepsi yaitu, perhatian yang selektif, gangguan yang selektif, dan mengingat kembali yang selektif.

Faktor-faktor persepsi ini yaitu, perhatian, gangguan, dan mengingat kembali yang selektif, berarti bahwa pesmasar harus bekerja keras agar pesan yang disampaikan diterima.

3) Proses belajar

Proses belajar menjelaskan perubahan dalam prilaku seseorang yang timbul dari penglaman.

4) Kepercyaan dan sikap

${ }^{19}$ Leon G schiffman, "Perilaku Konsumen”, (edisi-7, Jakarta: indeks), hal 106.
Kepercyaan adalah suatu gagasan deskriptif yang dimiliki seseorang terhadap sesuatu. ${ }^{20}$

\subsection{Faktor-Faktor yang mempengaruhi Keputusan Nasabah}

a. Nilai taksir

Nilai taksir adalah nilai atau harga perkiraan tertentu yang akan dijadikan jaminan yang didasarkan pada harga jadi, pasar dan peraturan yang yang berlaku pada masa tertentu. Dalam menetukan nilai taksiran tidak boleh melebihi dari nilai pasar atau nilai taksir tidak boleh lebih renda dari harga pasar. ${ }^{21}$

Nilai taksir yang digunakan merupakan acuan yang digunakan untuk pencairan dana yang diberikan untuk mengurangi risiko dikemudian hari. Dikhawatirkan apabila terdapat nasabah yang tidak dapat melunasi pinjaman atau hanya membayar jasa simpanan, maka pegadaian Syariah melakukan pelelangan terhadap barang jaminan tersebut.

Sebelum menentukan nilai taksir, penaksir harus terlebih dahulu mengetahui berapa tingkat kadar emas yang akan dijaminkan. Dalam kandungan emas memiliki berbagai jumlah kadar karat dari 24 karat sampai 16 karat. Semakin tinggi jumlah karat yang dimiliki maka semakin tinggi pula harganya.

${ }^{20}$ Philip Kotler, "Manajemen Pemasaran", (Jilid 1, Jakarta: PT Indeks Kelompok Gramedia, 2005), hal 210.

${ }^{21}$ Fitriya Wati, Pengaruh Nilai Taksir Emas Terhadap Keputusan Nasabah Menggunakan Produk Gadai Emas Dipegadaian Syariah Cabang Blauran, Skripsi (UIN Sunan AmpelSurabaya, 2017), diakses, 10 januari 2018. 


\section{Jurnal Ilmu Perbankan dan Keuangan Syariah Vol. 1 No. 2 Tahun 2020}

Standar kadar karat pada perhiasan pada umumnya berkisar pada 18-22 karat. Hal ini maksudkan supaya perhiasan emas tidak gampang rusak, sebab emas murni mempunyai tingkat kelenturan yang tinggi. Emas murni sebenarnya mudah patah atau rusak, maka dibutuhkan logam lain untuk memperkuat.

Terdapat beberapa analisis pengujian yang dilakukan oleh penaksir untuk mengetahui kadar emas tersebut. Tujuan menguji emas adalah untuk memastikan suatu barang yang benarbenar emas, selanjutnya jika telah diyakini bahwa memng barang tersebut adalah emas maka perlu diketahui berapa kemurnian emas tersebut. Kemurnian ini disebut juga kadar karatase, dalam Bahasa sederhana disebut karat. Berikut beberapa analisis pengujian emas:

1. Analisis Fisik

a. Ditimang

Petugas konter layanan gadai akan menimang-nimang emas yang akan digadaikan oleh nasabah, dengan cara meletakkan barang pada telapak tangan, kemudian diangkat secara perlahan untuk memperkirakan berapa berate mas yang digadaikan.

b. Dilihat Warnanya

Petugas konter layanan gadai akan mengamati warna dari emas yang akan digadaikan untuk mengetahui keaslian dari emas tersebut. Emas yang digadaikan hanya emas kuningan dan merah (perhiasan) dan logam mulia (emas batangan).

c. Dijatuhkan

Apabila emas tersebut asli maka pada saat emas dijatuhkan akan mengeluarkan bunyi yang nyaring seperti logan terjatuh.

d. Dilihat Cap Tanggungannya

Dengan melihat tanda atau angka yang tertera pada bagian dalam emas dengan menggunakan kaca pembesar.

Angka atau kode tersebut digunakan untuk menghitung berapa besar nilai karatase dan taksiran emas tersebut. 22

\section{Analisi Kimia}

Analisis ini menggunakan alat bantu berupa bahan kimia, bahan yang dimaksud yakni $\mathrm{H}_{2} \mathrm{SO}_{4}$ dan $\mathrm{HaOh}$. Berikut prosedur pengujian kimia:

a. Barang uji emas digoreskan beberapa kali ke batu hitam RX.

b. Sebagian goresan pada batu diteteskan larutan $\mathrm{H}_{2} \mathrm{SO}_{4}$ dan akan terjadi reaksi kimia, tunggu beberapa detik kemudian keringkan dengan kapas. Maka yang akan terjadi pada warna goresan, yakni:

1) Hilang sama sekali, maka barang dinyatakan bukan emas.

2) Sedikit pudar, maka barang dinyatakan emas berkadar dibawah 16 karat.

3) Warna tetap sama, maka dinyatakan emas berkadar diatas 16 karat.

c. Selanjutnya, pada goresan emas disisi lainnya diteteskan larutan $\mathrm{NaOH}$, dan terdapat tiga reaksi kimia yang terjadi pada warna goresan:

1) Pudar sekali, maka kadar emas dibawah 23 karat, diatas 16 karat.

2) Sedikit pudar, maka kadar emas berkisar 23 karat atau 22 karat.

${ }^{22}$ Ikka Virganita Nurcahyan, Analisis Metode Penaksiran Emas Pada Produk Gadai Emas Di Bank Syariah Mandiri Area Cirebon, Skripsi (Institut Agama Islam Negeri (IAIN) Purwokerto 2017), Diakses, 10 Januari 2018. 


\section{Jurnal Ilmu Perbankan dan Keuangan Syariah Vol. 1 No. 2 Tahun 2020}

3) Warna tetap sama, maka emas tersebut berkadar 24 karat (emas murni). ${ }^{23}$

\section{Analisis Berat Jenis}

Pengujian dengan berat jenis, setiap benda mempunyai berat jenis atau SG (specific gravity).Emas dapat dengan mudah dikenali dengan mencari berat jenisnya.Berat jenis adalah masa zat itu dibagi dengan volumenya.

Metode berat jenis (specific gravity) merupakan suatu metode analisis melalui pendekatan angkat berat jenis yang diperbolehkan pada logam tersebut. Setiap benda padat, cair, maupun gasakan mempunyai berat yang berlainanuntuuk setiap isi (volume) yang sama. Angka yang menunjukkan berat tersebut dengan metode berat jenis:

a. Siapkan peralatan yang berupa timbangan.

b. Timbang berat kering emas.

c. Timbang berat basah emas.

d. Hitung volume kemudian bandingkan dengan table berat jenis. $^{24}$

\section{METODE PENELITIAN}

Pendekatan yang digunakan dalam penelitian ini adalah pendekatan kuantitaif, karena penelitian ini terfokus

\footnotetext{
${ }^{23}$ Fitriya Wati, Pengaruh Nilai Taksir Emas Terhadap Keputusan Nasabah Menggunakan Produk Gadai Emas Dipegadaian Syariah Cabang Blauran, Skripsi (UIN Sunan AmpelSurabaya, 2017), diakses, 10 januari 2019.

${ }^{24}$ Ikka Virganita Nurcahyan, Analisis Metode Penaksiran Emas Pada Produk Gadai Emas Di Bank Syariah Mandiri Area Cirebon, Skripsi (Institut Agama Islam Negeri (IAIN) Purwokerto 2017), diakses, 10 Januari 2018.
}

untuk mengetahui pengaruh faktorfaktor yang mempengaruhi keputusan nasabah dalam memilih gadai emas. Penelitian ini dilakukan di Bank Syariah Mandiri Cabang Palu dengan alamat Jalan Wolter Monginsidi No 77, Kota Palu Sulawesi Tengah

Peneliti memberikan questioner kepada 82 respondent nasabah Bank Mandiri Syariah. Quesioner menggunakan lima skala likert .

Teknik analisis data yang digunakan dalam penelitian ini adalah analisis kuantitaif, yaitu proses analisis terhadap data-data yang berbentuk angka dengan cara perhitungan secara statistik untuk mengukur kualitas produk dan desain terhadap keputusan pembelian produk gadai emas. Analisa data dilakukan melalui tahap uni validitas, reabilitas, uji regresi berganda, dan uji asumsi klasik. Untuk oembuktian hipotesis penulis menggunakan uji f dan uji t. ${ }^{25}$

\section{HASIL DAN PEMBAHASAN}

\subsection{Deskripsi Umum Subjek Penelitian}

Klasifikasi responden yang dilihat pada penelitian ini meliputi jenis kelamin, usia, pekerjaan, pendapatan perbulan dari masing-masing responden. Dalam penelitian ini responden berjumlah 82 nasabah gadai di Bank Syariah Mandiri Cabang Palu.Untuk mengumpulkan data primer yang dilakukan dengan menyebarkan kuisioner kepada responden. Setelah

${ }^{25}$ Nurdin, N., \& Mir'atun, M. a. (2018). Do Government And Private Sharia Commercial Banks Practice Similar Financial Social Responsibility Disclosure. Hunafa: Jurnal Studia Islamika, 15(2), 285-321. 


\section{Jurnal Ilmu Perbankan dan Keuangan Syariah

melihat hasil penyebaran, maka dapat diketahui gambaran umum nasabah gadai di BSM sebagai berikut :

Table 1

Klasifikasi responden berdasarkan jenis kelamin

\begin{tabular}{|c|c|c|c|}
\hline No & Jenis kelamin & Jumlah & presentase \\
\hline 1 & Laki-laki & 14 & $17 \%$ \\
\hline 2 & Perempuan & 68 & $83 \%$ \\
\hline \multicolumn{2}{|c|}{ Total } & 82 & $100 \%$ \\
\hline
\end{tabular}

Sumber data yang telah diolah(terlampir)

Berdasarkan tabel 1 dapat dilihat bahwa nasabah gadai di Bank Syariah Mandiri Cabang Palu yang berjenis kelamin laki-laki sebanyak 14orang dengan presentase $17 \%$ dan yang berjenis kelamin perempuan sebanyak 68 orang dengan presentase $83 \%$. Total dari keseluruhan responden sebanyak 82 orang. Dari keterangan diatas menunjukkan bahwa rata-rata nasabah yang menggadaikan emas di Bank Syariah Mandiri cabang Palu adalah perempuan dengan presentase $83 \%$.

Tabel 2

Klasifikasi responden berdasarkan usia

\begin{tabular}{|r|c|c|c|}
\hline No & Usia & Jumlah & Presentase \\
\hline 1. & $>16$ tahun & 3 & $4 \%$ \\
\hline 2. & $26-35$ tahun & 20 & $24 \%$ \\
\hline 3. & $36-45$ tahun & 46 & $56 \%$ \\
\hline 4. & $>45$ tahun & 13 & $16 \%$ \\
\hline \multicolumn{2}{|c|}{ Total } & 82 & $100 \%$ \\
\hline
\end{tabular}

Sumber: data yang telah diolah (terlampir)

Berdasarkan tabel 2 menunjukkan bahwa nasabah gadai di Bank Syariah Mandiri Cabang Palu yang berusia $>16$ tahun berjumlah 3 orang dengan presentase $4 \%$, kemudian nasabah yang berusia 26-35 tahun berjumlah 20 orang dengan presentase $24 \%$, sedangkan yang berusia 36-45 tahun berjumlah 46 orang dengan presentase $56 \%$ dan yang berusia $>45$ tahun berjumlah 16 orang dengan presetase $16 \%$. Total dari keseluruhan responden adalah sebanyak
82 orang. Dari keterangan diatas menunjukkan bahwa rata-rata nasabah gadai di Bank Syariah Mandiri Cabang Palu adalah berusia 36-45 tahun dengan presentase $56 \%$.

\subsection{Analisis Data}

\section{Uji Validitas}

Uji ini dilakukan untuk mengetahui validitas butir-butir pernyataan dari hasil kuisioner. Uji validitas ini menunjukkan sejauh mana suatu alat ukur mampu mengukur apa yang ingin diukur.

\begin{tabular}{|c|c|c|c|c|}
\hline & & $\begin{array}{c}\text { Tabel } 3 \\
\text { Hasil uji validita }\end{array}$ & & \\
\hline Variabel & $\begin{array}{c}\text { Item } \\
\text { pernyataan }\end{array}$ & $\begin{array}{l}\text { Corrected item } \\
\text { tosal comrelation } \\
\text { (R-hitung) }\end{array}$ & R katis & Ket \\
\hline Nilai & 1 & 0,323 & 0,30 & Valld \\
\hline $\begin{array}{l}\text { Taksiran } \\
\text { (X1) }\end{array}$ & $\frac{2}{3}$ & $\begin{array}{l}0,424 \\
0,351\end{array}$ & $\begin{array}{l}0,30 \\
0,30\end{array}$ & $\begin{array}{l}\text { Valid } \\
\text { Valid }\end{array}$ \\
\hline & 4 & 0,486 & 0,30 & Valid \\
\hline Biaya Iarah & I & 0.410 & 0,30 & Valid \\
\hline (X2) & $\frac{2}{3}$ & $\begin{array}{l}0,448 \\
0.518\end{array}$ & $\begin{array}{l}0,30 \\
030\end{array}$ & $\begin{array}{l}\text { Valid } \\
\text { Valid }\end{array}$ \\
\hline Pelayanan & 1 & 0,402 & 0,30 & Valid \\
\hline (X3) & 2 & 0.397 & 0,30 & Valid \\
\hline & 3 & 0,420 & 0,30 & Valid \\
\hline & 4 & 0.553 & 0,30 & Valid \\
\hline Kegutusan & 1 & 0,420 & 0,30 & Valid \\
\hline Nasabah & 2 & 0.418 & 0,30 & Valid \\
\hline (Y) & 3 & 0.455 & 0,30 & Valid \\
\hline
\end{tabular}

Dari tabel 3 diatas, menunjukkan bahwa nilairhitung pada kolom Corrected item total correlationpada masing-masing variabel diatas dinyatakan semua pernyataan valid dikarenakan $\mathrm{r}$ hitung lebih besar daripada $r$ kritis.

\section{Uji Reliabilitas}

Melakukan pengujian reliabilitas dalam penelitian ini digunakan program SPSS ( statistical packaged for social siences) versi 16 dimana dalam mengukur reliabilitas disini menggunakan uji statistic cronbach's alpha. Suatu instrument dinyatakan reliable jika cronbach's alpha lebih dari 0,60. 


\section{Jurnal Ilmu Perbankan dan Keuangan Syariah

Hsil

pengujian reliabelmenggunakan alat bantu oleh statistic SPSS versi 16 for windows dapat diketahui sebagai mana tabel berikut.

Tabel 4
Hasil uji reliable
\begin{tabular}{|c|c|c|c|}
\hline Variabel & $\begin{array}{c}\text { Reliability } \\
\text { coefficiens }\end{array}$ & $\begin{array}{c}\text { Cronbach's } \\
\text { alpha }\end{array}$ & Keterangan \\
\hline Nilai Taksir (X1) & 4 item & 0,609 & Reliable \\
\hline Biaya Ijarah (X2) & 3item & 0,647 & Reliable \\
\hline Pelayanan (X3) & 4item & 0,660 & Reliable \\
\hline Keputusan & 3item & 0,608 & Reliable \\
Nasabah (Y) & & & \\
\hline
\end{tabular}

Dari tabel 4 diatas, dapat diketahui bahwa masing-masing variabel memiliki cronbach's alpa lebih dari 0,60, yang artinya bahwa variabel $\mathrm{X} 1, \mathrm{X} 2, \mathrm{X} 3$ dan $\mathrm{Y}$ adalah reliabel.

\section{Analisis Regresi Linier Berganda}

Analisis regresi linier berganda digunakan dalam penelitian ini dengan tujuan untuk mengetahui ada tidaknya pengaruh variabel bebas terhadap variabel terikat. Perhitungan statistic dalam analisis regresi linier berganda yang digunakan dalam penelitian ini adalah dengan menggunakan bantuan program SPSS for windows versi 16.

Tabel 5

Ringkasan Hasil Regresi

Coefficients $^{\mathrm{a}}$

\begin{tabular}{|c|c|c|c|c|c|c|}
\hline \multirow{2}{*}{\multicolumn{2}{|c|}{ Model }} & \multicolumn{2}{|c|}{$\begin{array}{c}\text { Unstandardized } \\
\text { Coefficients }\end{array}$} & \multirow{2}{*}{\begin{tabular}{|c|}
$\begin{array}{c}\text { Standardized } \\
\text { Coefficients }\end{array}$ \\
Beta \\
\end{tabular}} & \multirow[b]{2}{*}{$t$} & \multirow[b]{2}{*}{ Sig. } \\
\hline & & B & $\begin{array}{l}\text { Std. } \\
\text { Error }\end{array}$ & & & \\
\hline & (Constant) & .728 & 2.490 & & .292 & .771 \\
\hline \multirow{2}{*}{1} & nilai taksir & .118 & .067 & .177 & 1.764 & .082 \\
\hline & biaya ijarah & .338 & .125 & .271 & 2.705 & .008 \\
\hline & pelayanan & .355 & .078 & .442 & 4.558 & .000 \\
\hline
\end{tabular}

Dari hasil tabel 5 diatas, apabila ditulis dalam bentuk standardized dari persamaan regresinya adalah sebagai berikut:

$$
\begin{aligned}
& Y=a+b_{1} X_{1}+b_{2} X_{2}+b_{3} X_{3}+e_{i} \\
& \quad=0,728+0,118 X 1+0,338 X 2+0,355 X 3 \\
& +e_{i}
\end{aligned}
$$

Hasil perhitungan diatas dapat dijelaskan yaitu:

a. Nilai konstanta (a) sebesar 0,728 ini berarti jika variabel independen yaitu nilai taksir (X1), biaya ijarah (X2), dan pelayanan (X3), diasumsikan bernilai (0), maka keputusan nasabah memilih produk gadai emas sebesar 0,728.

b. Nilai koefisien nilai taksir (X1) sebesar 0,118 dan bernilai positif maka ini menunjukkan nilai taksir mempunyai hubungan yang searah. Hal ini mengandung arti bahwa jika variabel nilai taksir baik, maka keputusan nasabah memilih produk gadai emas (Y) akan meningkat dengan pengaruh sebesar $11,8 \%$.

c. Nilai koefisien biaya ijarah (X2) sebesar 0,338 dan bernilai positif maka hal ini menunjukkan biaya ijarah mempunyai hubungan yang searah. Hal ini mengandung arti bahwa jika variabel biaya ijarah baik, maka keputusan nasabah memilih produk gadai emas (Y) akan meningkat dengan pengaruh sebesar $33,8 \%$.

d. Nilai koefisien pelayanan (X3) sebesar 0,355 dan bernilai positif maka ini menunjukkan pelayanan mempunyai hubungan yang seara. Hal ini mengandung arti bahwa jika variabel pelayanan baik, maka variabel keputusan nasabah memilih produk gadaiemas (Y) akan meningkat dengan pengaruh sebesar $35,5 \%$.

\subsection{Hasil Pengujian Hipotesis}

\section{Uji F (Serentak)}

Pengujian ini digunakan untuk mengetahui apa yang ingin diketahui apakah variabel independen (X) 


\section{Jurnal Ilmu Perbankan dan Keuangan Syariah Vol. 1 No. 2 Tahun 2020}

berpengaruh secara bersama-sama memberikan kribusi secara signifikan terhadap variabel dependen.

\begin{tabular}{|c|c|c|c|c|c|c|}
\hline \multicolumn{7}{|c|}{ ANOVA $^{\mathrm{D}}$} \\
\hline & & $\begin{array}{l}\text { Sum of } \\
\text { Squares }\end{array}$ & df & $\begin{array}{l}\text { Mean } \\
\text { Square }\end{array}$ & $\mathrm{F}$ & Sig. \\
\hline \multirow[t]{3}{*}{1} & Regression & 42.884 & 3 & 14.295 & 10.146 & $.000^{a}$ \\
\hline & Residual & 109.896 & 78 & 1.409 & & \\
\hline & Tota1 & 152.780 & 81 & & & \\
\hline \multicolumn{7}{|c|}{$\begin{array}{l}\text { a. Predictors: (Constant), pelayanan, biaya ijarah } \\
\text {, nilai taksir }\end{array}$} \\
\hline & ependent Va & ble: keput & $\operatorname{san} n$ & 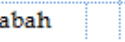 & & \\
\hline
\end{tabular}

Berdasarkan hasil uji anova atau $\mathrm{F}$ tes diproleh nilai Fhitung sebesar 10.146 $>$ F tabel 2,72 dengan nilai sig sebesar 0,000 dibandingkan alpha 0,05. Dengan demikian hasil ini memberikan makna bahwa variabel nilai taksir, biaya ijarah, dan pelayanan secara serentak berpengaruh positif dan signifikan terhadap keputusan nasabah $(\mathrm{Y})$.

\section{Uji T(Parsial)}

Uji ini digunakan untuk menguji apakah variabel independen benarbenar memberikan kontribusi terhadap variabel dependen.Dibawah ini adalah tabel hasil uji $\mathrm{T}$ pada tabel coeficients.

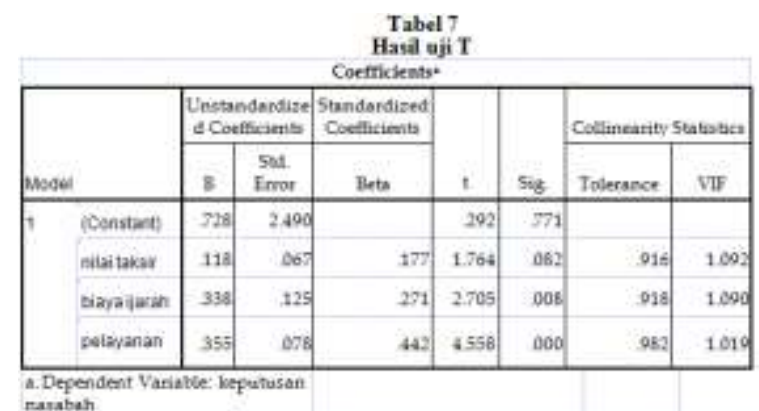

Berdasarkan hasil perhitungan statistik uji $\mathrm{T}$ dari 3 variabel independen yang dimasukkan dalam model regresi ini terlihat bahwa:

a. Nilai taksir (X1) diperoleh $\mathrm{T}$ hitung $1,764<\mathrm{T}$ tabel 1,994 dengan nilai sig
$0,082>0,05$. Dengan nilai ini memberi makna bahwa secara parsial variabel nilai taksir(X1) tidak memberikan pengaruh positif dansignifikanterhadap keputusan nasabah (Y). adapun besaran pengaruhnya dapat dilihat pada kolom beta. Besaran pengaruh variabel X1 terhadap Y yaitu $17,7 \%$.

b. Biaya ijarah (X2) diproleh $\mathrm{T}$ hitung 2,705 > T tabel 1,994 dengan sig 0,008 $<0,05$. Dengan ini memberikan makna bahwa secara parsial variabel biaya ijarah (X2)memberikan pengaruh secara positif dan signifikan terhadap keputusan nasabah (Y). Adapun besaran pengaruhnya dilihat dari kolom beta. Besaran pengaruh variabel X2 terhadap Y yaitu 27,1\%.

c. Pelayanan (X3) diproleh $\mathrm{T}$ hitung 4,558 > T tabel 1,990 dengan sig 0,000 $<0,05$. Dengan ini memberi makna bahwa secara parsial variabel pelayanan (X3) memberi pengaruh secara positif dan signifikan terhadap keputusan nasabah (Y). Adapun besaran pengaruhnya bisa dilihat dari klom beta. Besaran pengaruh variabel X3 terhadap Y yaitu $44,2 \%$.

d. Jadi, dari beberapa variabel $X$ yang diteliti. Maka, variabel yang paling besar pengaruhnya terhadap keputusan memilih produk gadai emas adalah variabel pelayanan dengan besaran pengaruh yaitu $44,2 \%$.

\subsection{Koefisien Determinasi}

Analisis koefisien determinasi dilakukan untuk mengetahui seberapa besar perensate kontribusi independen $(\mathrm{X})$ terhadap variabel dependen (Y).dari hasil perhitungan melalui alat ukur 


\section{Jurnal Ilmu Perbankan dan Keuangan Syariah Vol. 1 No. 2 Tahun 2020}

statistick SPSS 16 for windows didapatkan nilai koefisien determinasi sebagai berikut.

\section{Tabel 8}

Hasil Uji Koefisien Determinasi

\begin{tabular}{|c|c|c|c|c|}
\hline \multicolumn{5}{|c|}{ Model Summaryb } \\
\hline Model & $\mathrm{R}$ & $\begin{array}{c}\mathrm{R} \\
\text { Square }\end{array}$ & $\begin{array}{l}\text { Adjusted } \\
\text { R Square }\end{array}$ & $\begin{array}{l}\text { Std. Error of } \\
\text { the Estimate }\end{array}$ \\
\hline 1 & $.530^{\mathrm{a}}$ & .281 & .253 & 1.187 \\
\hline \multicolumn{5}{|c|}{$\begin{array}{l}\text { a. Predictors: (Constant), pelayanan, biaya } \\
\text { ijarah, nilai taksir }\end{array}$} \\
\hline \multicolumn{5}{|c|}{ b. Dependent Variable: keputusan nasabah } \\
\hline
\end{tabular}

Tampilan output SPSS model summery besarnya adalah $28,1 \%$ hal ini berarti bahwa variasi variabel keputusan nasabah dalam memilih produk gadai emas (Y) dipengaruhi oleh perubahan variabel independen yang terdiri dari nilai taksir, biaya ijarah dan pelayanan sebaesar 28,1\%. Sedangkan sisanya $71,9 \%$ dipengaruhi oleh variabel yang tidak diteliti dalam penelitian ini.

\subsection{Pembahasan}

Hasil pengujian dengan menggunakan analisis regresi berganda dengan SPSS 16 for windows, menunjukkan bahwa secara serentak variabel $\mathrm{X} 1, \mathrm{X} 2$ dan $\mathrm{X} 3$ memiliki pengaruh positif terhadap keputusan nasabah dalam memilih produk gadai emas di BSM cabang Palu. Begitu pula dengan pengaruh masing-masing variabel secara parsial masing-masing memiliki pengaruh dengan besaran pengaruh yang berbeda.

a. Pengaruh Nilai Taksir Terhadap Keputusan Nasabah Dalam Memilih Produk Gadai Emas

Nilai taksir (X1) diperoleh nilaiT hitung 1,764 < T tabel 1,994 degan sig
$0,082>0,05$. Dengan nilai ini memberi makna bahwa secara parsial variabel nilai taksir (X1) tidak berpengaruh secarapositif dan signifikan terhadap keputusan nasabah (Y).Adapun besaran pengaruhnya dapat dilihat pada kolom Beta. Besaran pengaruh variabel X1 terhadap $Y$ yaitu 17,7\%.

Hasil penelitian ini tidak sejalan dengan penelitian yang dilakukan oleh Arifah Afriana dengan judul penelitian "Pengaruh Nilai Taksiran Dan Biaya Ijarah Terhadap

Keputusan Nasabah Melakukan Gadai E mas Di Pengadaian Syariah Cabang Abd ullah Dg.Sirua Makassar" 26

Hal ini dikarenakan sebagian besar nasabah BSM cabang Palu kurang memahami nilai taksiran emas.

\section{b. Pengaruh Biaya Ijarah Terhadap Keputusan Nasabah Dalam Memilih Produk Gadai Emas}

Biaya ijarah (X2) diproleh T hitung 2,705 > T tabel 1,994 dengan sig 0,008 < 0,05 . Dengan nilai ini memberikan pengaruh secara positifdan signifikan terhadap keputusan nasabah (Y).Adapun besaran pengaruhnya dilihat dari kolom beta. Besaran pengaruh variabel $\mathrm{X} 2$ terhadap $\mathrm{Y}$ yaitu $27,1 \%$.

Dalam penelitian ini ditemukan bahwa biaya ijarah merupakan faktor yang mempengaruhi keputusan nasabah, dimana hasil wawancara kepada suvervisor layanan gadai bank

${ }^{26}$ Arifah Afriana, Pengaruh Nilai Taksiran Dan Biaya Ijarah Terhadap Keputusan Nasabah Melakukan Gadai Emas Di Pegadaian Syariah Cabang Abdullah Dg Siruah Makassar, Skripsi (Universitas Islam Negri Alauddin Makassar 2016), Http://Repositori.Uinalauddin.Ac.Id/6248/Skripsi, Diakses 5 Desember 2018.

e-ISSN: $2686-6625$ 


\section{Jurnal Ilmu Perbankan dan Keuangan Syariah Vol. 1 No. 2 Tahun 2020}

syariah mandiri cabang palu menjelaskan bahwa $85 \%$ nasabah menginginkan biaya ijarah yang relatif murah.Seperti biaya ijarah yang dikeluarkan oleh bank syariah mandiri lebih murah dibandingkan lembaga keuangan yang lainnya.

\section{c. Pengaruh Pelayanan Terhadap Keputusan Nasabah Dalam Memilih Produk Gadai Emas}

Pelayanan (X3) diproleh $\mathrm{T}$ hitung $4,558>\mathrm{T}$ tabel 1,994 dengan sig $0,000<$ 0,05.Dengan nilai ini memberi makna bahwa variabel pelayanan (X3) memberi pengaruh secara positif dan signifikanterhadap keputusan nasabah (Y).Adapun besaran pengaruhnya bisa dilihat dari kolom Beta. Besaran pengaruh variabel $\mathrm{X} 3$ terhadap $\mathrm{Y}$ yaitu $44,2 \%$.

Hal ini dikarena petugas layanan gadai mampu berkomunikasi dengan baik dan sesuai dengan etika-etika islam seperti jujur kepada nasabah dalam menyampaikan nilai taksiran dan biaya ijarah produk gadai yang ditawarkan oleh bank syariah mandiri, berkata sopan yang dapat dutunjukkan oleh tutur bahasa yang baik pada nasabah, sikap saling menghargai dalam melayani nasabah tanpa membedakan latar belakang dan status social nasabah, ramah dalam menjelaskan ketika ada yang bertanya, bicara dengan terang dan jelas terkait akad dan kontrak yang akan dilakukan sehingga tidak ada kebingungan dari nasabah serta selalu siap dan sigap melayani diwaktu jam kerja agar nasabah tidak menunggu lama.

Hasil penelitian ini tidak berbeda jauh dengan penelitian sebelumnyayang dilakukan oleh Yalisma Dewi dengan judul "pengaruh nilai taksir, biaya ijarah, promosi dan pelayanan terhadap keputusan nasabah menggunakan jasa pembiayaan gadai emas syariah (studi kasus bank BNI syariah cabang Kusumanegara Yogyakarta)" ${ }^{27}$

d. Pengaruh Nilai Taksiran, Biaya Ijarah Dan Pelayanan Terhadap Keputusan Nasabah Dalam Memilih Produk Gadai Emas

Secara serentak ketiga variabel independen yaitu nilai taksir yang memilimalisir unsur gharar, biaya ijarah yang tidak mengandung unsur riba dan pelayanan yang relevan dengan ajaran islam berdasarkan hasil perhitungan statistic menunjukkan nilai Fhitung sebesar $10.146>$ F tabel 2,72 dengan nilai sig sebesar 0,000 dibandingkan alpha 0,05 . Sehingga dapat dinyatakan berpengaruh secara positif dan signifikan terhadap variabel dependen yaitu keputusan nasabah gadai emas syariah.

Berdasarkan hasil perhitungan adjusted $R$ square yaitu sebesar 0,253. Ini menunjukkan bahwa keputusan nasabah gadai emas syariah pada bank syariah mandiri cabang Palu dipengaruhi oleh 3 variabel yaitu nilai taksir, biaya ijarah dan pelayanan sebesar $28,1 \%$ dan $71,9 \%$ dipengaruhi oleh variabel lain yang tidak diteliti dalam penelitian ini.

27Yalisma Dewi, Pengaruh Nilai Taksir, Biaya Ijarah, Promosi Dan Pelayanan Terhadap Keputusan Nasabah Menggunakan Jasa Pembiayaan Gadai Emas Syariah (Studi Kasus Pada Bank BNI Syariah Cabang Kusumanegara, Yogyakarta), Skripsi (Universitas Islam Negeri Sunan Kalijaga Yogyakarta 2013), Http://Digilib.UinSuka.Ac.Id/11340/Skripsi, Diakses 5 Desember 2019. 


\section{Jurnal Ilmu Perbankan dan Keuangan Syariah

e. Perspektif Ekonomi Islam Terhadap Keputusan Nasabah Memilih Produk Gadai Emas

Gadai merupakan suatu perjanjian atau akad dalam bermuamalah yang dilakukan oleh kedua belah pihak dalam bentuk hutang piutang dengan menyerahkan suatu barang sebagai jaminan atas hutang tersebut.Perjanjian gadai dibenarkan dalam surah albaqarah ayat 283 .

Barang tanggungan tersebut bagi nasabah adalah barang jaminan yang berupa emas.Dengan adanya factor kebutuhan, hal ini dapat dijumpai dalam pendapatnya as-saukani dalam skripsi amri yang mengemukakan bahwa "barang siapa dalam perjalanan melakukan perjanjian hutang piutang dan tidak dijumpai seorang pun penulis maka untuk mengikatnya (hutang piutang) diadakan jaminan yang dipegang. ${ }^{28}$

Jadi, adanya hutang piutang dikarena adanya kebutuhan yang mendesak dan gadai dalam perspektif ekonomi islam diperbolehkan dengan ditinjau dari akad gadai dengan keabsahan akad berdasarkan rukunnya menurut islam yaitu aqid, sighat, marhun dan murtahin.

\section{Kesimpulan}

${ }^{28}$ Amri, Penerapan Prinsip Ekonomi Islam Terhadap Pelaksanaan Gadai Sawah (Massanra Galung) Di Dusun Bocco-Bocco'e Desa Wecudai Kecamatan Pammana Kabupaten Wajo, Skripsi (Fakultas Ekonomi Dan Bisnis Islam Universitas Islam Negri Alauddin Makassar 2018),http: / / repositori.uinalauddin.ac.id/id/eprint/8797Diakses
Berdasarkan penelitian tentang analisis faktor - faktor yang mempengaruhi keputusan nasabah dalam memilih produk gadai emas pada bank syariah mandiri cabang Palu, maka diproleh kesimpulan bahwa Faktor faktor yang mempengaruhi nasabah adalah biaya ijarah dengan besaran pengaruh 27,1\% dan pelayanan dengan besaran pengaruh 44,2\%, sedangkan nilai taksir tidak dengan besaran pengaruh 17,7\% yang berarti nilai taksir tidak berpengaruh terhadap keputusan nasabah memilih produk gadai emas di Bank Syariah Mandiri Cabang Palu.

Faktor yang paling dominan berpengaruh secara signifikan adalah variabel pelayanan dimana $\mathrm{T}$ hitung $4,558>\mathrm{T}$ tabel 1,990 yang menyatakan pelayanan berpengaruh secara positif dan signifikan terhadap keputusan nasabah dalam memilih produk gadai emas di Bank Syariah Mandiri Cabang Palu dengan besaran pengaruh sebesar $44,2 \%$.

\section{Daftar Pustaka}

A, Karim, Adiwarman. Bank Islam: AnalisisFiqih Dan Keuangan. Jakarta: PT RajagrafindoPersada, 2004.

Abdullah, Thamrin. Francis Tantri. Manajemen Pemasaran. Jakarta: PT RajawaliPers, 2013.

Aksara, Binarupa. Prilaku Konsumen Jilid 1. Jakarta: Binarupa Aksara, 1994.

Anshori, Abdul Ghofur. Gadai Syariah Di Indonesia. Jakarta: Gadjah Mada University Pers, 2007.

Ascarya.Akad Dan Produk Bank Syariah. Jakarta: PT Rajawali Pers, 2011. 


\section{Jurnal Ilmu Perbankan dan Keuangan Syariah \\ Vol. 1 No. 2 Tahun 2020}

Assauri, Sofjan. Manajemen Pemasaran. Jakarta: PT Rajawali Pers, 2013.

Bank Syariah Mandiri Provinsi Sulawesi Tengah Cabang Palu

Bank syariah mandiri, annual report

Biduanto, Apri. Manajemen Pemasaran. Yogyakarta: Penerbit Ombak, 2015.

Buku Saku Bank Syariah Mandiri.

Fatwa DSN Mui No. 9/DsnMui/Vi/2000 Tentang Akad Ijarah.

G Schiffman, Leon.Prilaku Konsumen Edisi 7. Jakarta: Indeks.

Ghafur, Ruslan Abdul. Konsep Gadai (ArRahn), Fiqih, 01 Maret 2008. MsiUii, 2008.

Hajar Al-Atsqalani, Ibnu. Bulughul Maram. Beirut Dar El Fiker, 1994

Hasan, Iqbal. Pokok - Pokok Materi Statistik 1 (Statistic Deskriptif). Jakarta: PT BumiAksara, 2003.

Ifham, Ahmad. IniLho Bank Syariah!: Memahami Bank Syariah Dengan Mudah. Jakarta: PT Gramedia, 2015.

J, Stiadi, Nugroho. Prilaku Konsumen: Konsep Dan Implikasiluntuk Strategi Dan Penelitian Pemasaran. Jakarta: Kencana, 2003.

Kasmir. Dasar-Dasar Perbankan. Jakarta: PT Rajagrafindo Persada, 2003.

Kasmir.Manajemen Perbankan -Edisi Revisi. Jakarta: PT Rajawali Pers, 2012.

Keller, Kotler. Manajemen Pemasaran. Jakarta: Indeks, 2006.

Kementrian Agama, Al-Quran dan Terjemahan

Kotler, Philip. Manajemen Pemasaran Jilid 1. Jakarta: PT Indeks Kelompok Gramedia, 2005.
Lampiyoadi, Rambat, Manajemen PemasaranJasa. Salemba Empat, 2001.

Nugraha, Aria Gung. Gambaran Umum Usaha Pegadaian Syariah, Perum Pegadaian Cabang Batam.

Nurdin, N. (2016). The Roles of Information Technology in Islamic Bank Knowledge Management: A study of Two Syariah Banks in Palu. Hunafa: Jurnal Studia Islamika, 13(2), 181217.

Nurdin, N., \& Mir'atun, M. a. (2018). Do Government And Private Sharia Commercial Banks Practice Similar Financial Social Responsibility Disclosure. Hunafa: Jurnal Studia Islamika, 15(2), 285321.

Nurdin, N., \& Yusuf, K. (2020). Knowledge management lifecycle in Islamic bank: the case of syariah banks in Indonesia. International Journal of Knowledge Management Studies, 11(1), 59-80. https://doi.org/10.1504/ijkms.20 20.105073

Prasetijo, Ristiyanti Dan John Joilhalauw. Prilaku Konsumen. Yogyakarta: Andi, 2005.

Prasetyo, Bambang Dan Lina Miftahul Jannah. Metode Penilitian Kuantitaif: Teori Dan Aplikasi. Jakarta: PT Rajagrafindo Persada, 2012.

Rivai, Veithzal, Dkk. Bank And Financial Institution Manajemen. Jakarta: PT Rajagrafindo Persada, 2007.

Sholahuddin, Muhammad. Lembaga Keuangan Dan Ekonomi Islam. Yogyakarta: Penerbit Ombak, 2014. 


\section{Jurnal Ilmu Perbankan dan Keuangan Syariah \\ Vol. 1 No. 2 Tahun 2020}

Siregar, Syofian. Statistik Parametika Untuk Penelitian Kuantitatif: Dilengkapi Dengan Perhitungan Manual Dan Aplikasi Spss Versi 17. Jakarta: Bumi Aksara.

Suhendi, Hendi. Fiqih Muamalah. Jakarta: PT Rajawali Pers, 2013.

Umar, Husein. Riset Pemasaran Dan Prilaku Konsumen. Jakarta: PT Gramedia Pustaka Utama, 2000.

Wangsa Widjaja, A. Pembiayaan Bank Syariah. Jakarta: PtGramedia Pustaka Utama, 2012.

Afriana, Arifah. Pengaruh Nilai Taksir Dan Biaya Ijarah Terhadap Keputusan Nasabah Melakukan Gadai Emas Di Pegadaian Syariah Cabang Abdullah Dg Sirua Makassar.

Dewi, Yalisma. Pengaruh Nilai Taksir, Biaya - Biaya, Promosi Dan Pelayanan Terhadap Bank BNI Syariah Cabang Kusumanegara. Yogyakarta.

Iskandar, Yogi. Pengaruh Kesesuaian Kompensasi Terhadap Kinerja Karyawan Pada PT Bentoel Utama Cabang Palu.

Kartika Sari, Fajar. Pengaruh Kualitas Pelayanan Dan Prosedur Kredit Terhadap Keputusan Pengambilan Kredit Dengan Reference Grup Sebagai Variabel Moderating Pada Badan Kredit Desa (Bkd) Gombong.

Rifqi Damarjati, Ahmad. Analisis FaktorFaktor Yang Mempengaruhi Keputusan Nasabah Dalam
Menggunakan Produk Pembiayaan Gadai Emas Syariah (Studi Kasus Pada Bpd DIY Syariah Cabang Cik Di Tiro).

SamsulArifin, Mohammad. Pengaruh Nilai Taksir, Biaya - Biaya, Dan Pelayanan Terhadap Keputusan Nasabah Menggunakan Produk Emas Tunai Hebat (Eth) Di Solusi Tunai Cabang Krian Sidoarjo.

Seftiani, Ayu. Pengaruh Nilai Taksiran, Biaya - Biaya Dan Pelayanan, Terhadap Keputusan Nasabah Pada Pembiayaan Gadai Emas Syariah.

Virganita Nurcahyan, Ika. Analisis Metode Penaksiran Emas Pada Produk Gadai Emas Di Bank Syariah Mandiri Area Cirebon.

Wati, Fitriya. Pengaruh Nilai Taksir Emas Terhadap Keputusan Nasabah Menggunakan Produk Gadai Emas Dipegadaian Syariah Cabang lauran.

Ahmad Maulidizen. Aplikasi Gadai Emas Syari'ah: Studi Kasus Pada BRI Syari'ah Cabang Pekan baru

Rinda Asytuti. Kritik Penetapan Harga Ijarah Pada Gadai Emas (TinjauanFikih Dan Etika).

Trisnawati, Euis Komariah. Analisis Prosedur Gadai Emas Syariah Dalam Produk Rahn Emas IB. Hasanah (Study KasusPada PT Bank Syariah Cabang Bekasi). 